\title{
LIGHT INTERCEPTION, RADIATION USE EFFICIENCY AND BIOMASS ACCUMULATION RESPONSE OF MAIZE TO INTEGRATED NUTRIENT MANAGEMENT UNDER DROUGHT STRESS CONDITIONS
}

\author{
Muhammad Saqib RANDHAWA ${ }^{1}$, Muhammad MAQSOOD ${ }^{l}$, Muhammad Asif SHEHZAD ${ }^{2 *}$, Muhammad \\ Umer CHATTHA ${ }^{1}$, Muhammad Bilal CHATTHA ${ }^{3}$, Fahim NAWAZ ${ }^{2}$, Sanaullah YASIN ${ }^{4}$, Tasawer ABBAS ${ }^{1}$, \\ Muhammad Mohsin NAWAZI, Rana Dildar KHAN ${ }^{I}$, Usman ZULFIQAR \\ ${ }^{1}$ University of Agriculture, Faculty of Agriculture, Department of Agronomy, Faisalabad, PAKISTAN \\ ${ }^{2}$ Muhammad Nawaz Shareef University of Agriculture, Faculty of Agriculture \& Environmental Sciences, \\ Department of Agronomy, Multan, PAKISTAN \\ ${ }^{3}$ University of the Punjab, Institute of Agricultural Sciences, Lahore, PAKISTAN \\ ${ }^{4}$ Cotton Research Station Ghotki, Pakistan Central Cotton Committee, Multan, PAKISTAN \\ ${ }^{*}$ Corresponding author: asifbukhari01@gmail.com
}

Received: 09.12.2015

\begin{abstract}
In order to alleviate the drought adversities on maize (Zea mays $L$.)biomass accumulation and radiation use efficiency (RUE), a field study was conducted under drought stress levels of $D_{1}=$ well-watered, $D_{2}=$ drought stress at blister stage, $D_{3}=$ drought stress at blister and dough stages; and integrated nutrition levels, $N_{0}=$ control, $\mathrm{N}_{1}=\mathrm{NPK}, 125-60-62 \mathrm{~kg} \mathrm{ha}^{-1}, \mathrm{~N}_{2}=\mathrm{NPK}, 125-60-62 \mathrm{~kg} \mathrm{ha}^{-1}+$ FYM at $10 \mathrm{t} \mathrm{ha}^{-1}, \mathrm{~N}_{3}=\mathrm{NPK}, 125-60-62 \mathrm{~kg}$ $\mathrm{ha}^{-1}+$ FYM at $15 \mathrm{t} \mathrm{ha}^{-1}, \mathrm{~N}_{4}=$ NPK, 250-120-125 kg ha-1, $\mathrm{N}_{5}=\mathrm{NPK}, 250-120-125 \mathrm{~kg} \mathrm{ha}^{-1}+$ FYM at $10 \mathrm{t} \mathrm{ha}^{-1}, \mathrm{~N}_{6}=$ NPK, 250-120-125 kg ha-1 + FYM at $15 \mathrm{t} \mathrm{ha}^{-1}$. Drought stress caused a significant decline in growth traits, interception of photosynthetically active radiation (PAR), RUE and finally biomass production. The highest leaf area index, leaf area duration, crop growth rate, net assimilation rate, interception of PAR and dry matter accumulation was recorded in plants applied with NPK $\left(250-120-125 \mathrm{~kg} \mathrm{ha}^{-1}\right)$ in combination with FYM $(15 \mathrm{t}$ $\mathrm{ha}^{-1}$ ), whereas only NPK application did not significantly improve light interception and dry biomass production. Fraction of intercepted (Fi) radiation was significantly improved by integrated nutrient management under well-watered as well as drought stress conditions. A substantial decrease in total dry matter and grain yield basis RUE was recorded from higher to lower plant nutrition rates, as the highest value of RUE was found with treated plants of $250-120-125 \mathrm{~kg} \mathrm{NPK} \mathrm{ha}^{-1}+$ FYM at $15 \mathrm{t} \mathrm{ha}^{-1}$. Thus, our study demonstrates that supplemental NPK with FYM is an effective strategy to boost the drought tolerance through improved RUE and biomass accumulation in maize.
\end{abstract}

Keywords: Drought, radiation use efficiency, intercepted PAR, dry matter, NPK

\section{INTRODUCTION}

Cumulative dry matter production of maize (Zea mays L.) crop mainly depends upon the intercepted photosynthetically active radiation (PAR) through plant leaves. The efficiency of accumulated radiation interception is a linear function of leaf area of the plants, leaf shape as well as leaf decoration that influences the rate of photosynthesis and transpiration (M'hamed et al., 2014). The total dry matter (TDM) produced in crop plants is positively related to the intercepted PAR, the efficiency of conversion of radiations to biomass and the slope that indicates radiation use efficiency (RUE) (Liu et al., 2012). Severe reduction in plant growth occurred primarily by reduction in RUE through decline in photosynthesis under drought stress. The deficiency of water reduces the PAR interception due to rolling up the plant leaves. Upon prolonged water deficit conditions, the number and total leaf area is reduced, eventually reduces the crop's ability of radiation interception. In addition to change in TDM production, drought stress also affects leaf conductance in crop plants which reduces net photosynthesis through disturbance in rates of growth respiration and maintenance respiration. It is also the main cause of accumulation of carbon in plant roots and shoots, which decreases shoot growth more than the root growth, finally leads to reduced RUE in drought stressed plants (Ibrahim et al., 1997; Omidi et al., 2012). RUE directly associates with nutrient concentrations and its partitioning in the leaves. Its deficiency declines the photosynthetic rate of the crop canopies, alters the plant water status and gas exchange rate by reducing the permeability of roots to water (Sinclair and Horie, 1989). Supplemental NPK possesses positive impact on plant growth and 
development by changing canopy structure and its size, thus altering RUE. The expanded leaf area by nutrients application is the main determinant of PAR interception and its utilization towards accumulation of dry biomass; i.e. nitrogen supply considered as primary constituent of chlorophyll pigments that drive to maximize the photosynthetic capacity in maize plants, resulting in higher crop growth (Akmal et al., 2010; Zahoor et al., 2010). Constant use of inorganic fertilizers in intensive cropping system resulted in unbalancing of the nutrients in the soil solution that has deleterious effects on crop yield as well as on soil health. Sole application of organic or inorganic nutrients not more essential to improve the crop productivity; therefore, judicious use of organic and inorganic fertilizers helped great to maintain the crop productivity (Randhawa et al., 2012). Although numerous studies underlined the positive effects of inorganic and organic nutrients in mitigating the adversities of drought, while limited information is available on integrated effects of chemical fertilizers with organic nutrients on maize growth under water limited conditions. Hence, the present field study was emphasized to investigate the impact of combined use of NPK fertilizers with farm yard manure (FYM) in maize crop based on light interception, RUE and biomass production under drought stress conditions.

\section{MATERIALS AND METHODS}

The trial was carried out on sandy clay loam soil at the Agronomic Research Field, University of Agriculture Faisalabad, Pakistan for two consecutive cropping seasons (2009 and 2010). The area of experiments was located at $73^{\circ}$ East longitude, $31^{\circ}$ North latitude and an altitude of 185 meters above the sea level with flat alluvial plain made by river Chenab and Ravi and with semi-arid climate. The prescribed area is specially preferred for canal irrigation system. Physical and chemical characteristics of the experimental soil were determined at the depth of $30 \mathrm{~cm}$ (Table 1). Mean monthly weather data of maize crop for both growing seasons was described in Table 2 .

Table 1. Physical and chemical analysis of the soil

\begin{tabular}{ccccccccc}
\hline \multirow{2}{*}{$\begin{array}{c}\text { Growing } \\
\text { season }\end{array}$} & $\begin{array}{c}\text { Sand } \\
(\boldsymbol{\%})\end{array}$ & $\begin{array}{c}\text { Silt } \\
(\boldsymbol{\%})\end{array}$ & $\begin{array}{c}\text { Clay } \\
(\boldsymbol{\%})\end{array}$ & $\mathbf{p H}$ & $\begin{array}{c}\mathbf{O M} \\
(\boldsymbol{\%})\end{array}$ & $\begin{array}{c}\text { Total N } \\
(\boldsymbol{\%})\end{array}$ & $\begin{array}{c}\text { Available P } \mathbf{( m g} \\
\left.\mathbf{k g}^{-1}\right)\end{array}$ & $\begin{array}{c}\text { Available K }(\mathbf{m g} \\
\left.\mathbf{k g}^{-1}\right)\end{array}$ \\
\hline 2009 & 64 & 17 & 19 & 7.96 & 0.78 & 0.051 & 7.11 & 179 \\
2010 & 63 & 15 & 22 & 8.05 & 0.91 & 0.053 & 7.25 & 183 \\
\hline
\end{tabular}

Table 2. Weather data of maize crop during the experimentation

\begin{tabular}{|c|c|c|c|c|c|c|c|c|c|c|}
\hline & \multicolumn{4}{|c|}{ Temperature } & \multirow{2}{*}{\multicolumn{2}{|c|}{ Rainfall (mm) }} & \multirow{2}{*}{\multicolumn{2}{|c|}{ R.H (\%) }} & \multirow{2}{*}{\multicolumn{2}{|c|}{ SS (h) }} \\
\hline & \multicolumn{2}{|c|}{ Temp Min. $\left({ }^{\circ} \mathrm{C}\right)$} & \multicolumn{2}{|c|}{ Temp Max. $\left({ }^{\circ} \mathrm{C}\right)$} & & & & & & \\
\hline & 2009 & 2010 & 2009 & 2010 & 2009 & 2010 & 2009 & 2010 & 2009 & 2010 \\
\hline August & 27.60 & 26.11 & 36.61 & 34.91 & 116.00 & 226.60 & 65.77 & 74.65 & 8.40 & 6.01 \\
\hline September & 24.43 & 23.32 & 36.25 & 33.93 & 20.60 & 86.50 & 61.00 & 66.77 & 9.21 & 7.88 \\
\hline October & 17.06 & 19.68 & 32.71 & 32.89 & 17.50 & 0.00 & 57.90 & 59.58 & 8.88 & 7.57 \\
\hline November & 10.75 & 10.52 & 25.68 & 27.08 & 0.70 & 0.00 & 64.67 & 62.27 & 6.26 & 8.53 \\
\hline
\end{tabular}

The experiment was planned under RCBD with splitplot design in a net plot size of $3.0 \mathrm{~m} \times 5.0 \mathrm{~m}$. Drought stress treatments in main while integrated nutrition treatments were put in sub-plots within three triplicates. Drought stress treatments comprised of $\mathrm{D}_{1}=$ Wellwatered, $\mathrm{D}_{2}=$ Drought stress at blister stage, $\mathrm{D}_{3}=$ Drought stress at blister and dough stages; while integrated organic and inorganic levels included $\mathrm{N}_{0}=$ Control, $\mathrm{N}_{1}=$ NPK, 125-60-62 kg ha-1 $\mathrm{N}_{2}=$ NPK, 125-60$62 \mathrm{~kg} \mathrm{ha}^{-1}+\mathrm{FYM}$ at $10 \mathrm{t} \mathrm{ha}^{-1}, \mathrm{~N}_{3}=\mathrm{NPK}, 125-60-62 \mathrm{~kg}$ $\mathrm{ha}^{-1}+\mathrm{FYM}$ at $15 \mathrm{t} \mathrm{ha}^{-1}, \mathrm{~N}_{4}=\mathrm{NPK}, 250-120-125 \mathrm{~kg} \mathrm{ha}^{-1}$, $\mathrm{N}_{5}=\mathrm{NPK}, 250-120-125 \mathrm{~kg} \mathrm{ha}^{-1}+\mathrm{FYM}$ at $10 \mathrm{t} \mathrm{ha}^{-1}, \mathrm{~N}_{6}=$ NPK, 250-120-125 kg ha-1 + FYM at $15 \mathrm{t} \mathrm{ha}^{-1}$. Maize hybrid 'R-2331' was sown during $1^{\text {st }}$ week of August in both cropping seasons (2009 and 2010). Single row hand drill was used to plant the seeds $\left(30 \mathrm{~kg} \mathrm{ha}^{-1}\right)$ in $75 \mathrm{~cm}$ apart rows by keeping $20 \mathrm{~cm}$ plant to plant distance. In control plots $\left(\mathrm{D}_{1}\right)$, normal six irrigations were applied at third leaf, ninth leaf, tasseling, blister, milking and dough stages. At drought stress level of $\mathrm{D}_{2}$, irrigation was skipped only at blister stage, while at drought stress level of $\mathrm{D}_{3}$; irrigation was skipped at blister and dough stages. The nitrogen $(\mathrm{N})$, phosphorus $\left(\mathrm{P}_{2} \mathrm{O}_{5}\right)$ and potassium $\left(\mathrm{K}_{2} \mathrm{O}\right)$ was applied in accordance with treatments in the form of urea, di-ammonium phosphate and sulphate of potash, respectively. All $\mathrm{P}_{2} \mathrm{O}_{5}, \mathrm{~K}_{2} \mathrm{O}$ and one third of the total $\mathrm{N}$ were applied at the time of sowing, while remaining one third $\mathrm{N}$ was applied two times 15 days after sowing and at tasseling stage. Crop was harvested manually on $2^{\text {nd }}$ week of November during both years.

Fraction of intercepted radiation $(\mathrm{Fi})$ was estimated from leaf area index using the exponential attenuation equation suggested by Monteith and Elston, (1983); Fi = 1 - $\exp (-\mathrm{K} \times \mathrm{LAI})$. Where, $\mathrm{K}$ is an extinction coefficient for total solar radiation equal to 0.7 for maize (Lindquist et al., 2005). Photo-synthetically active radiation (PAR) was assumed to be equal to one half of the total incident radiation (Szeicz, 1974). Multiplying this total by the 
appropriate estimates of $\mathrm{Fi}$ gave an estimate of the amount of radiation intercepted by a crop canopy $(\mathrm{Sa}) ; \mathrm{Sa}=\mathrm{Fi} \times$ $\mathrm{Si}$. Where, $\mathrm{Si}$ is the total amount of incident PAR. RUE for TDM and grain yield (GY) was calculated as;

$$
\begin{aligned}
& \mathrm{RUE}_{\mathrm{TDM}}=\mathrm{TDM} / \sum \mathrm{Sa} \\
& \mathrm{RUE}_{\mathrm{GY}}=\text { Grain yield } / \sum \mathrm{Sa}
\end{aligned}
$$

Leaf area was measured by selecting ten plants at random from each treatment at a regular interval of $15 \mathrm{~d}$ The sampling was initiated 30 days after sowing (DAS) and terminated 90 DAS. Fresh weight of separated leaves was recorded at each sampling, and a sub sample of $30 \mathrm{~g}$ was used to measure the leaf area. Leaf area was determined by length-width method; Leaf area = Length $\times$ Width $\times \mathrm{K}$. Where, $\mathrm{K}$ is the correction factor with a value of 0.75 . Then leaf area index (LAI) was calculated by using the formula; LAI = Leaf area / Land area. Leaf area duration $(\mathrm{LAD})$ was estimated as; $\mathrm{LAD}=\left(\mathrm{LAI}_{1}+\mathrm{LAI}_{2}\right) \times$ $\left(\mathrm{T}_{2}-\mathrm{T}_{1}\right) / 2$. Crop growth rate (CGR) was calculated by the formula of Beadle, (1987). CGR $\left(\mathrm{g} \mathrm{m}^{-2}\right.$ day $\left.^{-1}\right)=\left(\mathrm{W}_{2}-\mathrm{W}_{1}\right) /$ $\left(\mathrm{T}_{2}-\mathrm{T}_{1}\right)$; where, $\mathrm{W}_{1}$ and $\mathrm{W}_{2}$ are the total dry weights at time $T_{1}$ and $T_{2}$, respectively. Net assimilation rate (NAR) was calculated as; NAR $\left(\mathrm{g} \mathrm{m}^{-2}\right.$ day $\left.^{-1}\right)=$ TDM/LAD. TDM $\left(\mathrm{g} \mathrm{m}^{-2}\right)$ was determined at a regular interval of $15 \mathrm{~d}$ by selecting ten plants at random from each subplot. The collected samples were chaffed, thoroughly mixed and oven dried till $70^{\circ} \mathrm{C}$ to get dry matter.

Recorded data were analysed by "MSTAT" statistical computer package. Upon significance of treatments' effect
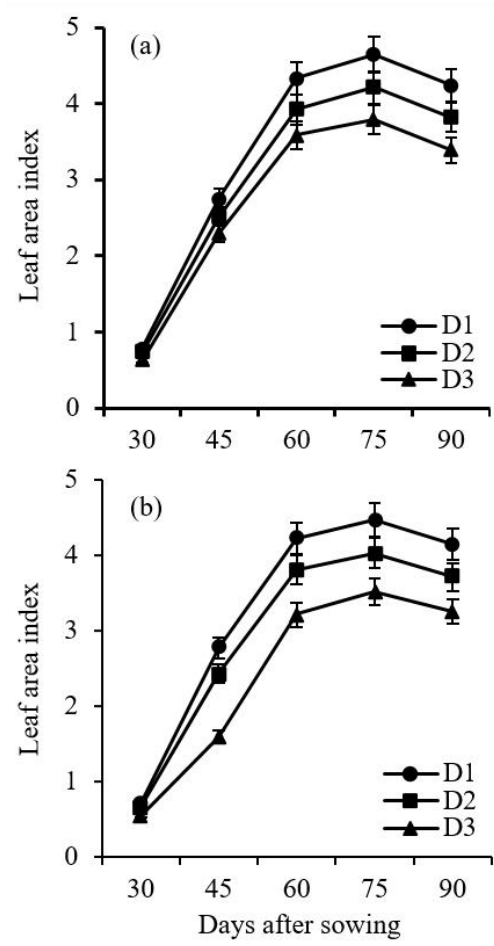

$(P \leq 0.05)$, least significance difference (LSD) test was used to compare their means (Steel et al., 1997).

\section{RESULTS}

Drought stress and integrated nutrition levels in maize crop during 2009 and 2010 significantly influenced the leaf area index. Initially, slight change in leaf area index was exposed, but progressively increased with the advancement of the growth period and reached its maximum value at 75 days after sowing (DAS), thereafter disposed to decline gradually. At 30 DAS, drought stress treatments caused relatively confined variations in leaf area index while became wider with the growth improvement. At 75 DAS harvest, the maximum values for leaf area index was attained from well watered plants that inclined to drop with decrease in irrigation regime; therefore the lowest leaf area index at same harvest was observed by imposing drought stress at blister and dough stages during both years of study (Figure 1). Integrated NPK with FYM considerably improved the leaf area index during the whole growing season; however, the highest leaf area index at 75 DAS harvest was produced by the crop that fertilized with 250-120-125 kg NPK ha-1 along with FYM at $15 \mathrm{t} \mathrm{ha}^{-1}$ and followed by $250-120-125 \mathrm{~kg}$ NPK ha-1 + FYM at $10 \mathrm{tha}^{-1}$ during both years. Contrarily, the minimum leaf area index was found for the crop grown without nutrition. Sole application of inorganic nutrients at $125-60-62 \mathrm{~kg} \mathrm{NPK} \mathrm{ha}^{-1}$ at the same harvest significantly reduced the leaf area index as compared to its integrated use with FYM (Figure 1). The interaction effect at all harvests was considered statistically non-significant.
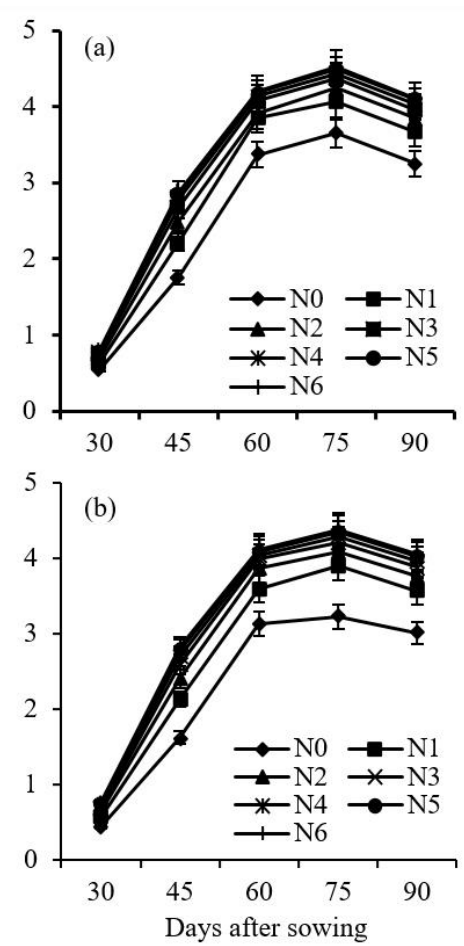

Figure 1. Effect of integrated NPK and FYM on leaf area index of maize under drought stress conditions during 2009 (a) and 2010 (b) 
A substantial increase in leaf area duration was depicted in well-watered plants, that was followed by drought stress at blister stage and drought imposed at both blister and dough growth stages during 2009. A similar trend appeared during crop growth period of 2010 (Figure 2). Among integrated plant nutrition levels, significantly the lowest leaf area duration was observed from control plots while the highest leaf area duration was recorded from the plots receiving FYM at $15 \mathrm{tha}^{-1}$ along with NPK rate of $250-120-125 \mathrm{~kg} \mathrm{ha}^{-1}$. Plants subjected to only inorganic nutrients resulted in poor performance, while addition of FYM to the growing crop significantly improved the leaf area duration during both years (Figure 2 ). Drought stress led to considerable decline in crop growth rate; however, maximum decrease in crop growth rate was observed when crop plants exposed to drought stress periods at blister and dough stages. Among integrated plant nutrition treatments, crop fertilized with 250-120-125 kg NPK ha-1 along with FYM at $15 \mathrm{t} \mathrm{ha}^{-1}$ improved maximum crop growth rate followed by the 250-120-125 kg NPK ha ${ }^{-1}$ plus FYM at $10 \mathrm{t} \mathrm{ha}^{-1}$ during 2009 (Figure 2). The same trend was observed in next year. Contrarily, the minimum crop growth rate was recorded from un-treatment plants during both years. Both, the drought stress and integrated nutrition levels showed a significant effect on net assimilation rate of maize during both cropping seasons (Figure 2). A positive linear relationship was found between net assimilation rate and irrigation regimes. As the drought stress reduced, net assimilation rate was improved and maximum was observed in case of well-watered conditions during both years. The mix use of NPK with FYM at higher rates of 250-120-125 kg NPK ha ${ }^{-1}$ along with FYM at $15 \mathrm{t} \mathrm{ha}^{-1}$ exhibited the maximum net assimilation rate of treated plants. Reduced rates for NPK (125-60-62 kg NPK ha-1) either sole application or along with FYM not behaved well in increasing the net assimilation rate during both years (Figure 2).
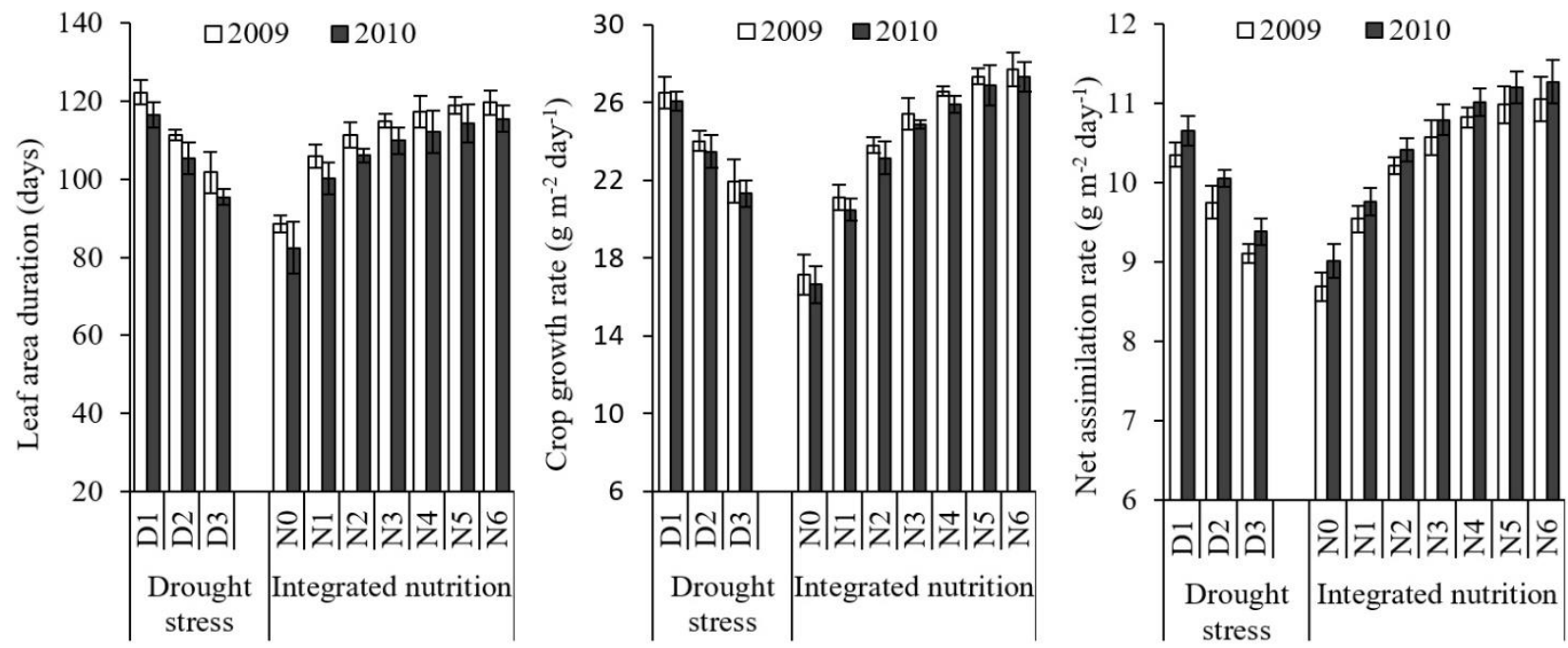

Figure 2. Effect of integrated NPK and FYM on leaf area duration, crop growth rate and net assimilation rate of maize under drought stress conditions during 2009 and 2010

The results referring Fi showed that interactive effects of drought stress and integrated nutrition rates were significant during both seasons, as the maximum Fi was recorded with 250-120-125 $\mathrm{kg} \mathrm{NPK} \mathrm{ha}^{-1}$ along with FYM at $15 \mathrm{t} \mathrm{ha}^{-1}$ under no stress which was statistically at par with 250-120-125 kg NPK ha-1 plus FYM at $10 \mathrm{t} \mathrm{ha}^{-1}$ and 250-120-125 kg NPK ha-1 during both years. Under drought stress, either at blister stage or at blister and dough stages, integrated use NPK rate of 250-120-125 kg $\mathrm{ha}^{-1}$ with FYM of $15 \mathrm{t} \mathrm{ha}^{-1}$ responded well in giving maximum Fi during both years of study (Figure 3). The effect of drought stress and integrated nutrition levels was significant in influencing the accumulated PAR during both cropping seasons. The maize crop grown under wellwatered conditions had maximum cumulative PAR. Contrarily, the lowest cumulative PAR was recorded for maize crop under stress conditions of blister and dough stages. Considering the integrated nutrition rates, increased level of integrated nutrition caused a progressive increase in cumulative PAR as maximum was recorded by the crop when fertilized with $250-120-125 \mathrm{~kg}^{\mathrm{NPK}} \mathrm{ha}^{-1}$ plus FYM at $15 \mathrm{t} \mathrm{ha}^{-1}$ in 2009 as compared to the crop grown without any nutrition. Similar trend was also observed in 2010 as well (Figure 4). The interactive effect affecting cumulative PAR was non-significant.

Seasonal trend of TDM production was significantly affected with drought stress conditions (Figure 5). At the harvest of 30 DAS, the TDM accumulation was lowest that increased gradually with crop growth; however, the maximum accumulation of TDM during both years was recorded at 75 DAS harvest with no drought followed by with drought stress at blister and combined at blister and dough growth stages. The plants fertilized with inorganic NPK along with FYM disclosed better performance in improving TDM accumulation. Significantly, the maximum TDM production was achieved with higher rates of 250-120-125 kg NPK ha-1 with FYM of $15 \mathrm{t} \mathrm{ha}^{-1}$ at 75 DAS during both years in contrast to control plots 
that showed the minimum TDM production at all harvests (Figure 5). A linear and positive correlation was found between TDM and cumulative PAR. This correlation was supported by regression model and showed the great dependence of TDM on radiation interception under drought stress and variable nutrition rates during both cropping seasons (Figure 6).

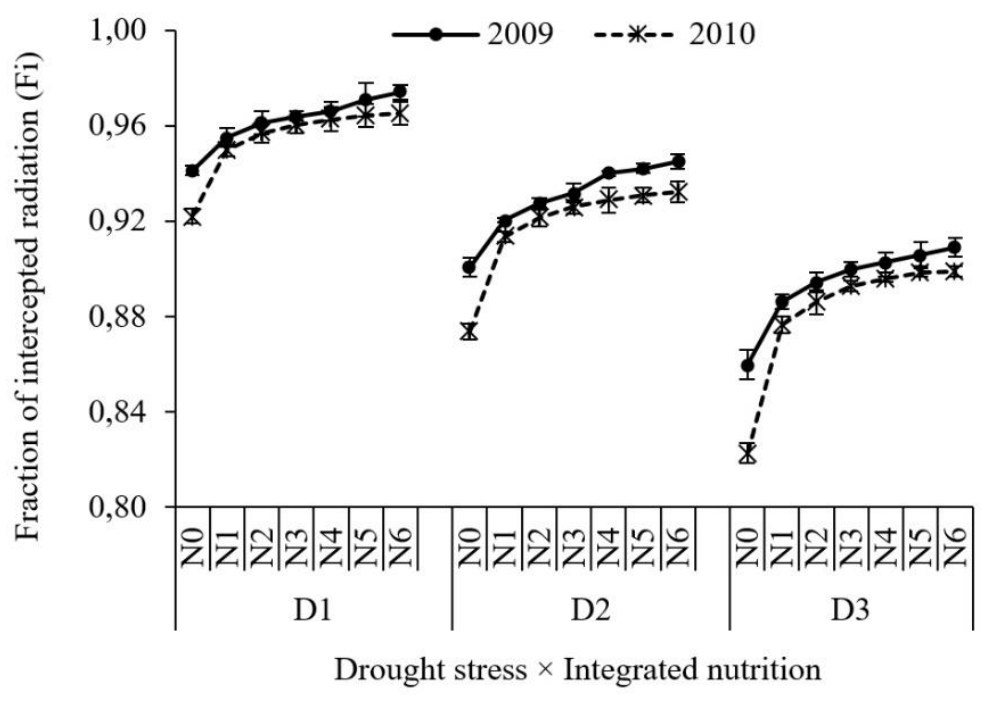

Figure 3. Effect of integrated NPK and FYM on fraction of intercepted radiation (Fi) of maize under drought stress conditions during 2009 and 2010
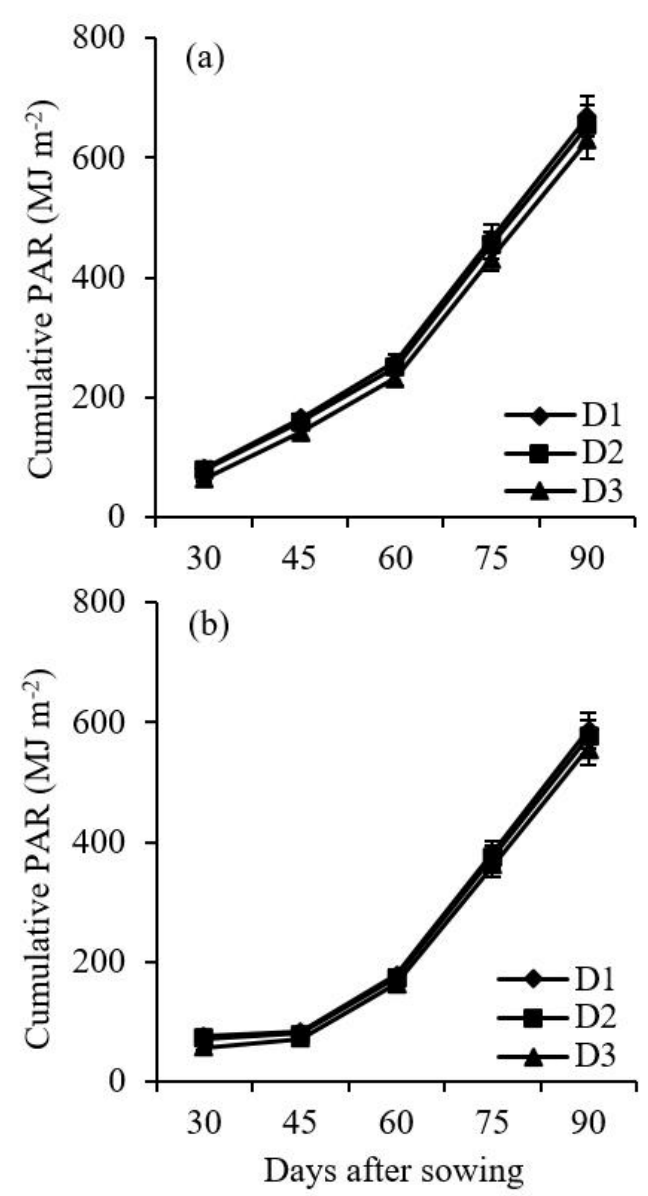
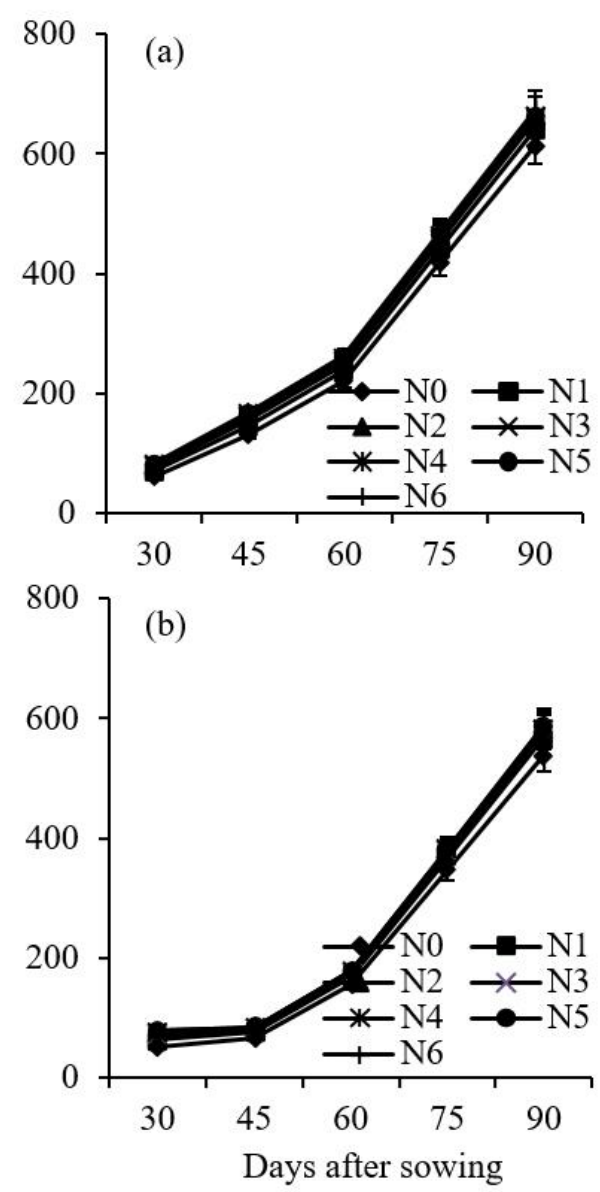

Figure 4. Effect of integrated NPK and FYM on cumulative PAR of maize under drought stress conditions during 2009 (a) and 2010 (b) 

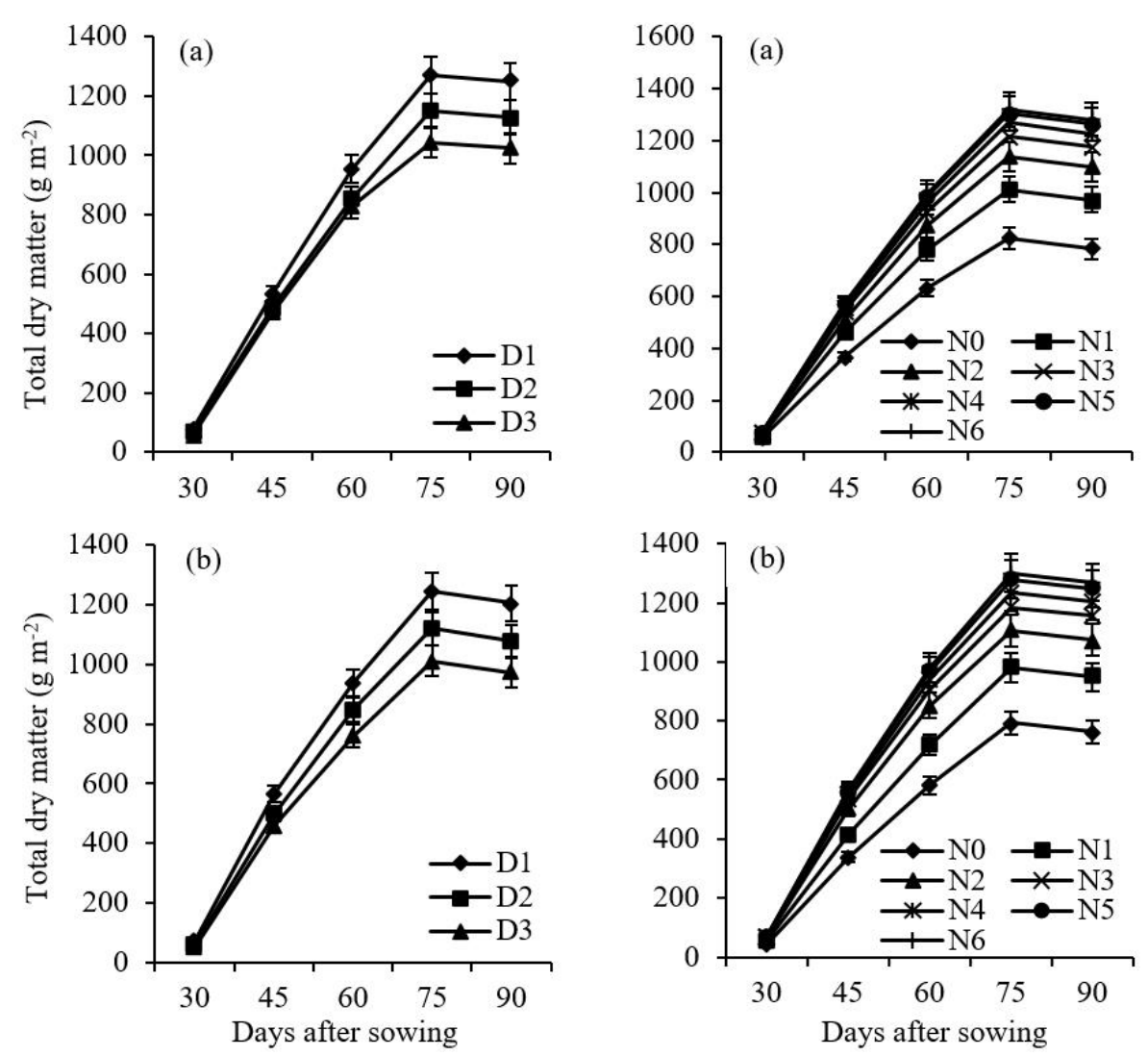

Figure 5. Effect of integrated NPK and FYM on total dry matter (TDM) of maize under drought stress conditions during 2009 (a) and 2010 (b)
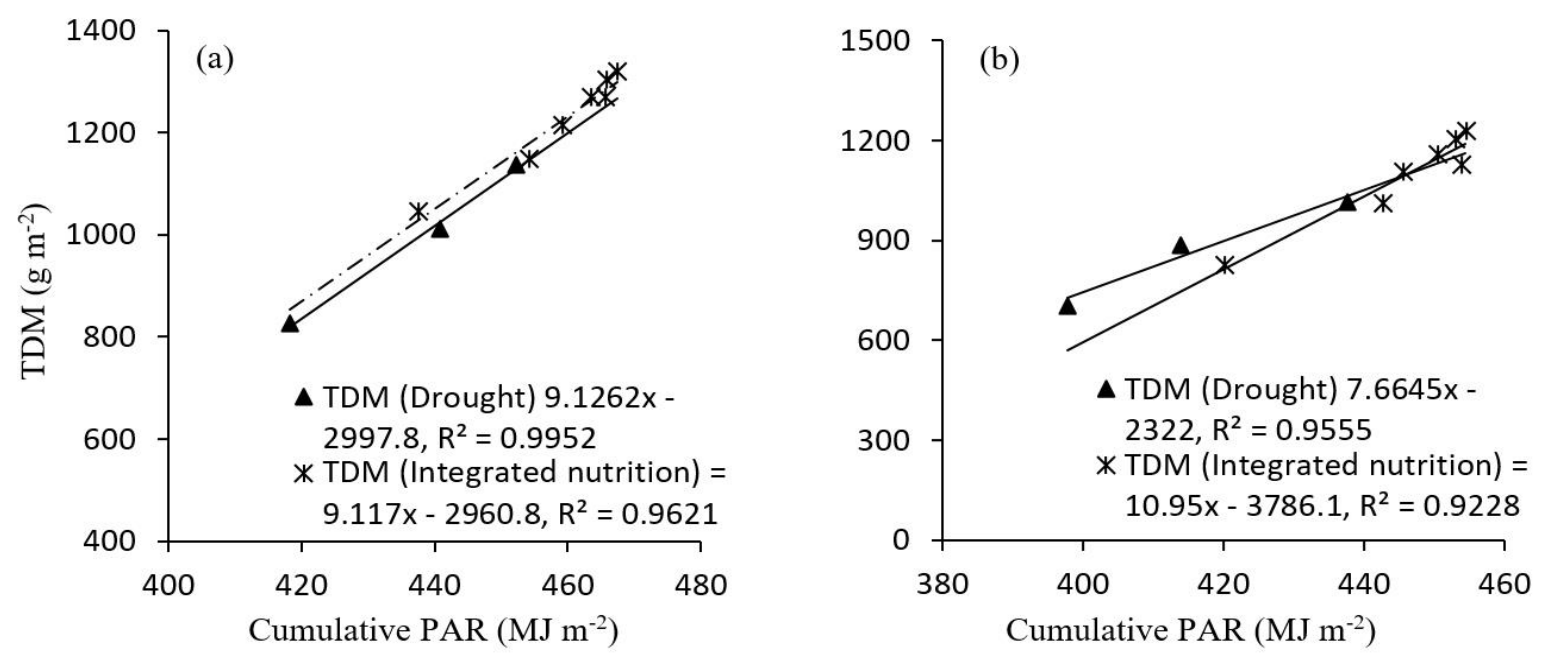

Figure 6. Relationship between total dry matter (TDM) and cumulative PAR during 2009 (a) and 2010 (b)

RUE of maize on TDM and GY basis was significantly affected by drought stress and integrated nutrition levels, while insignificant for their interaction during both years of 2009 and 2010 (Figure 7). A linear suppressive effect of drought stress on RUE TDM $_{\text {and }}$ RUE $_{\mathrm{GY}}$ was found significant during both years, as the higher RUE was recorded with no drought stress as compared to the drought stress at blister or at both blister and dough stages during both years. In 2009, among integrated nutrition levels, the maximum TDM and GY based RUE was shown in case of 250-120-125 kg NPK $\mathrm{ha}^{-1}$ along with FYM at $15 \mathrm{t} \mathrm{ha}^{-1}$ treatment, while the lowest was in the case of no fertilizer application. The same trend regarding integrated nutrition effects on TDM and GY based RUE was observed during 2010 (Figure 7). 

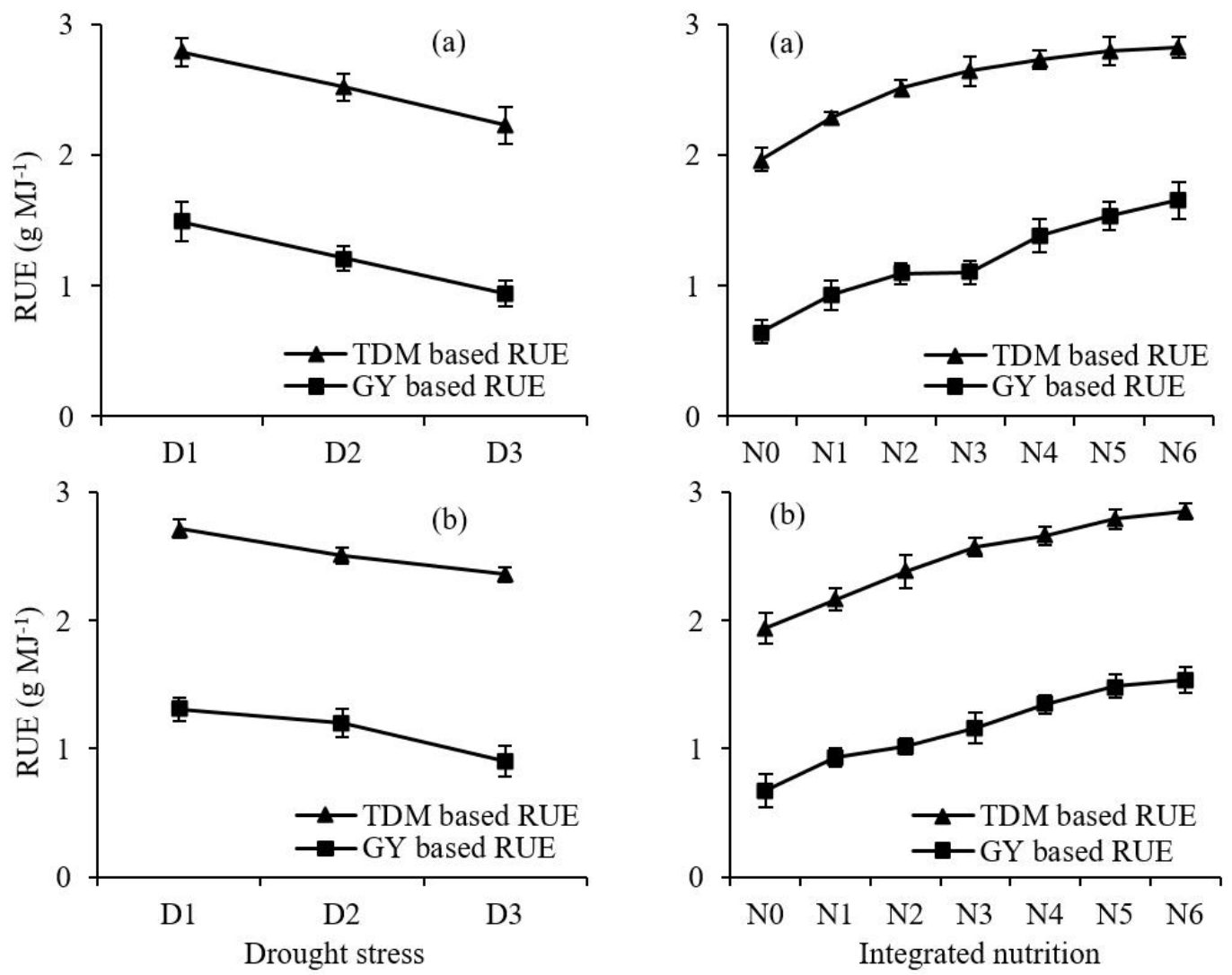

Figure 7. Effect of integrated NPK and FYM on radiation use efficiency (RUE) of maize under drought stress conditions during 2009 (a) and 2010 (b)

\section{DISCUSSION}

Accumulation of dry biomass, radiation interception, its use efficiency, and other growth related traits i.e. leaf area index, crop growth, and net assimilation rates considerably affected with drought stress; however, supplemental NPK with FYM helped more in improving the growth and development in maize. The reduced leaf expansion and its growth duration due to drought stress is a detriment to decline in photosynthesis by dropping transpiration efficiency (Gustav et al., 2008). Taiz and Zeiger, (2006); Farooq et al., (2009) reported that plant growth depends on cell division, differentiation, and its enlargement, also includes physiological, morphological and biochemical processes which are influenced by drought stress. Also, cell elongation is considered to be most sensitive physiological event which can be obstructed due to reduced turgor pressure through interrupting flow of water from xylem towards surrounding cells, eventually reduced leaf expansion, crop growth and net assimilation rates. The decrease in leaf area duration due to a notable cut in leaf area index because of small sized leaves production under drought stress conditions (Hussein et al., 2011). The results of present study specified that application of FYM in mixture with inorganic NPK improved the growth performance of maize. The higher rates for NPK (250-120-125 kg ha-1) and FYM (15 $\left.\mathrm{t} \mathrm{ha}^{-1}\right)$ produced maximum leaf area index, leaf area duration, crop growth rate, and net assimilation rate. In fact, the incorporation of FYM with inorganic nutrients enhances the growth of leaves, chlorophyll contents and assimilation capacity of plants through better nitrogen absorption and its higher photosynthetic efficiency; thus improving the leaf surface area (Ali et al., 2015).

In current results, reduced irrigation regimes significantly decreased $\mathrm{Fi}$ and cumulative PAR. The decrease in radiation interception under drought stress conditions might be the result of decline in leaf surface area due to rolling of leaves. It has also been reported that decline in leaf area index, Fi and cumulative PAR is due to impaired canopy development, accelerated leaf senescence and changes in orientation of leaf (Hayatu et al., 2014). As analysis specified that the integrated use of NPK (250-120-125 kg ha-1) with FYM (15 t ha-1) imposed significant impacts on accumulated PAR in well-watered as well as drought stress conditions. The maximum cumulative PAR via promoting leaf expansion by application of FYM along with inorganic NPK attributed to higher availability of nutrients through favourable moisture regimes in the soil rhizosphere due to efficient use of nutrients from faster mineralization of FYM. Its application and incorporation reduces the evaporation demand possibly due to softness of the root zone by manures application that leads to more root proliferation in the soil to meet the plant water requirements (Khalili et al., 2008; Khan et al., 2009). Several reports also described that integrated nutrient management of NPK along with FYM considerably increased the crop growth 
might be due to higher accessibility of nutrients to the plants besides of increased biological properties and water holding capacity of the soil. Furthermore, the deficiency symptoms of secondary-macro and micronutrients were prevalent on crop plants through alone application of NPK without FYM (Sohu et al., 2015).

Indeed, significant influence of drought stress and NPK fertilization with FYM was exhibited on TDM production of maize. The decrease in dry biomass accumulation by means of drought stress conditions was more evident in present study. The reduction in TDM production due to moisture stress is reliable with the stomatal closure, leads to reduced $\mathrm{CO}_{2}$ fixation, therefore decreasing cell division and enlargement finally restrictive to cellular metabolism (Jones, 1992). Increased TDM production through combined inorganic NPK and organic manures might be due to slow release of nutrients from FYM, helped more in decomposition of organic manures by microorganisms, thereby enhanced the availability of nutrients that leads to protein synthesis finally resulted in higher TDM production (Uikey et al., 2015). The differential behaviour of maize regarding dry matter production in response to availability of nutrients could rise from variation in cumulative light interception by the canopy, RUE and partitioning among different organs (Quanqi et al., 2008). Furthermore, TDM accumulation in relation to PAR was also confirmed by regression model. A strong correlation between TDM and PAR was observed under drought and integrated nutrient management. $\mathrm{R}^{2}$ values for TDM under drought stress were 0.99 and 0.95 during the study years of 2009 and 2010, respectively; while were 0.96 and 0.92 under integrated nutrient management during both years.

RUE indicates the crop biomass accumulation relative to the light interception. Variations in TDM based RUE attributed to change in radiation interception which is a key function for the production of dry biomass (Scott et al., 2003). In current study, a progressive reduction in RUE $_{\text {TDM }}$ was ascribed with drought stress, as decrease in RUE $_{\text {TDM }}$ might be due to decline in canopy photosynthetic efficiency as a result of leaf senescence by means of drought stress (Bat-Oyun et al., 2011). Integrated use of inorganic NPK and FYM caused a positive change in RUE $_{\text {TDM }}$ because of increased dry matter production through quick leaf area development by maximum interception of incoming PAR. This rapid growth contributes towards a fast coverage of ground surface, capturing of carbon, ultimately favoring plant growth (Hamzei and Soltani, 2012). Maqsood et al., (2014) also reported that higher availability of nutrients to plants in the integrated plant nutrition system due to a faster mineralization of the incorporated organic matter in the soil leads towards higher RUE $\mathrm{TDM}_{\text {. }}$

In our results, significant differences in $\mathrm{RUE}_{\mathrm{GY}}$ were reported by drought stress and integrated use of NPK and FYM. A considerable decline in $\mathrm{RUE}_{\mathrm{GY}}$ of droughtstressed plants was due to fact that drought reduces the length of development stages, decreases the grain yield; finally drops the $\mathrm{RUE}_{\mathrm{GY}}$. A notable cut in $\mathrm{RUE}_{\mathrm{GY}}$ by imposing drought stress conditions was because of the injury in metabolic factors as per decline in chlorophyll pigments (Azam et al., 2002). Improvement in biomass accumulation by supplying enough water and fertilizer strongly associated with grain yield. Tewolde and Fernandez, (1997); Crecchio et al., (2001) described that balanced nutrition management of organic and inorganic nutrients improved the nutrient mobilization and contribution of nutrients to various vegetative and grain filling organs and active role of organic fertilizers in promoting the soil biological activity, finally enhanced the RUE $_{\mathrm{GY}}$.

\section{CONCLUSIONS}

Radiation interception, its use efficiency and biomass accumulation were markedly influenced by low water availability however, combined application of NPK and FYM showed a considerable impact on maize growth under water deficit conditions. Significant and positive change in $\mathrm{Fi}$ occurred with integrated use of NPK with FYM under well-watered or drought stress conditions. Regression analysis also proved that PAR is a key element for TDM accumulation under limited water supplies. Integrated NPK of $250-120-125 \mathrm{~kg} \mathrm{ha}^{-1}$ plus FYM at $15 \mathrm{t}$ ha $^{-1}$ were noted as the best rate to achieve high RUE and maximum biomass production in maize.

\section{LITERATURE CITED}

Akmal, M., Hameed-ur-rehman, Farhatullah, M. Asim and H. Akbar. 2010. Response of maize varieties to nitrogen application for leaf area profile, crop growth, yield and yield components. Pak. J. Bot. 42: 1941-1947.

Ali, K., M. Arif, S. Shah, Z. Hussain, A. Ali, S. Munir and H. Sher. 2015. Effect of organic and inorganic nutrients sources on phenology and growth of wheat. Pak. J. Bot. 47: 22152222.

Azam, M., A. Hussain, S.A. Wajid and M. Maqsood. 2002. Effect of sowing date, irrigation and plant densities on radiation interception and its utilization efficiency in lentils. Int. J. Agric. \& Biol. 04: 217-219.

Bat-Oyun, T., M. Shinoda and M. Tsubo. 2011. Effects of water and temperature stresses on radiation use efficiency in a semiarid grassland. J. Plant Interact. 7:214-224.

Beadle, C.L. 1987. Plant growth analysis. In techniques in bioproductivity and photosynthesis. $2^{\text {nd }}$ ed. Edited by Coomlos, J.D.O. Hall, S.P. Long and J.M.O. Scurlock. Pergamon press, Oxford, New York. PP. 21-23.

Crecchio, C., M. Curci., R. Mininni., P. Ricciuti and P. Ruggiero, 2001. Short term effects of municipal solid waste compost amendments on soil carbon and nitrogen content, some enzyme activities and genetic diversity. Biol. Fert. Soils. 34: 311-318.

Farooq, M., A. Wahid, N. Kobayashi, D. Fujita and S.M.A. Basra. 2009. Plant drought stress: effects, mechanisms and management. Agron. Sustain. Dev. 29: 185-212.

Gustav, O.A., I. Pereyra, V. Luciano, L. Leandra and L.A.N. Aguirrezabal. 2008. Genetic variability for leaf growth rate and duration under water deficit in sunflower: analysis of responses at cell, organ, and plant level. J. Exp. Bot. 59: 2221-2232.

Hamzei, J. and J. Soltani. 2012. Deficit irrigation of rapeseed for water-saving: Effects on biomass accumulation, light interception and radiation use efficiency under different $\mathrm{N}$ rates. Agric. Ecosys and Environ. 155: 153-160. 
Hayatu, M., S.Y. Muhammad and U.A. Habibu. 2014. Effect of water stress on the leaf relative water content and yield of some cowpea (Vigna Unguiculata (L) Walp.) genotype. Int. J. Sci. \& Technol. Res. 3: 148-152.

Hussein, M.M., M.M. Shaaban., A.M. El-Saady and A.A. ElSayed. 2011. Growth and photosynthetic pigments of fodder beet plants as affected by water regime and boron foliar fertilization. Nature Sci. 9: 72-79.

Ibrahim, L., M.F. Proe and A.D. Cameron. 1997. Main effects of nitrogen supply and drought stress upon whole-plant carbon allocation in poplar. Can. J. For. Res. 27: 1413-1419.

Jones, H.G. 1992. Plants and microclimate; a quantitative approach to environmental Physiology (2 ${ }^{\text {nd }}$ Edition). Cambridge University Press, Cambridge, UK.

Khalili, I., N. Akbari and M.R. Chaichi. 2008. Limited irrigation and phosphorus fertilizer effects on yield and yield components of grain sorghum (Sorghum bicolor L.var. Kimia). Amer. Eurasian J. Agric. \& Environ. Sci. 3: $697-$ 702.

Khan, A., M.T. Jan, K.B. Marwat and M. Arif. 2009. Organic and inorganic nitrogen treatments effects on plant and yield attributes of maize in a different tillage systems. Pak. J. Bot. 41: 99-108

Lindquist, J.L., T.J. Arkebauer, D.T. Walters, K.G. Gassman and A. Dobermann. 2005. Maize radiation use efficiency under optimal growth conditions. Agron. J. 97: 72-78.

Liu, T., F. Song, S. Liu and X. Zhu. 2012. Light interception and radiation use efficiency response to narrow-wide row planting patterns in maize. AJCS. 6: 506-513.

M'hamed, H.C., M. Rezig and M.B. Naceur. 2014. Deficit irrigation of durum wheat (Triticum durum Desf): Effects on total dry matter production, light interception and radiation use efficiency under different nitrogen rates. Sustain. Agric. Res. 4: 26-40.

Maqsood, M, M.A. Shehzad, Y. Ramzan and A. Sattar. 2014 Effect of nitrogen nutrition on growth, yield and radiation use efficiency of different wheat (Triticum aestivum L.) cultivars. Pak. J. Agri. Sci. 51: 441-448.

Monteith, J.L. and J.F. Elston. 1983. Performance and productivity of foliage in the field. In: The Growth and Functioning of Leaves (Eds.): J.E. Dale and F.L. Milthorpe. Camb. Univ. Press, Butterworths, London, pp. 499-518.
Omidi, A.H, K. Hamid, M. Philippe and S. Frederick. 2012. Effect of cultivar and water regime on yield and yield components in safflower (Carthamus tinctorius L.). Turk. J. Field Crops. 17: 10-15.

Quanqi, L., C. Yuhai, L. Mengyu, Z. Xunbo, Y. Songlie and D. Baodi. 2008. Effects of irrigation and planting patterns on radiation use efficiency and yield of winter wheat in North China. Agric. Water Manage. 95: 469-476.

Randhawa, M.S., M. Maqsood, S.A. Wajid and M. Anwar-ulHaq. 2012. Effect of integrated plant nutrition and irrigation scheduling on yield and yield components of maize (Zea mays L.). Pak. J. Agri. Sci. 49: 267-273.

Scott, G.D., J.E. Erickson and E.L. Kruger. 2003. Foliar morphology and canopy nitrogen as predictors of light-use efficiency in terrestrial vegetation. Agric. Forest Meteorol. 115: 163-171.

Sinclair, T.R. and T. Horie. 1989. Leaf nitrogen, photosynthesis and crop radiation use efficiency: A review. Crop Sci. 29: 90-98.

Sohu, I., A.W. Gandahi, G.R. Bhutto, M.S. Sarki and R. Gandahi. 2015. Growth and yield maximization of chickpea (Cicer arietinum) through integrated nutrient management applied to rice-chickpea cropping system. Sarhad J. Agric. 31: 131-138.

Steel, R.G.D., J.H. Torrie and D.A. Deckey. 1997. Principles and procedures of statistics, A biometrical approach. 3rd ed. McGraw Hill Book Co.Ink. New York: 400-428.

Szeicz, G. 1974. Solar radiation for plant growth. J. Appl. Ecol. 11: 617-36

Taiz L. and E. Zeiger. 2006. Plant Physiology, $4^{\text {th }}$ Ed., Sinauer Associates Inc. Publishers, Massachusetts.

Tewolde, H. and C.J. Fernandez. 1997. Vegetative and reproductive dry weight inhibition in nitrogen and phosphorus-deficient Pima cotton. J. Plant Nutr. 20: 219232.

Uikey, V., H. Verma and D. Nawange. 2015. Influence of organic, chemical and biofertilizer on growth and yield of pea. Agric. Sci. Digest. 35: 237-240.

Zahoor, A., M. Riaz, S. Ahmad, H. Ali, M.B. Khan, K. Javed, M.A. Anjum, M. Zia-ul-Haq and M.A. Khan. 2010. Ontogeny growth and radiation use efficiency of Helianthus annuus L., as affected by hybrids, nitrogenous regimes and planting geometry under irrigated arid conditions. Pak. J. Bot. 42: 3197-3207. 